UDC 94(477.82)«1906/1921»:329.63(=161.1)

DOI 10.24919/2519-058x.13.188668

\title{
Yaroslav TSETSYK
}

PhD (History), Associate Professor of the Department of Public Administration, Documentation and Information Activities of the National University of Water Management and Nature Management, 18 Mykhaylo Verbytskyi street, Rivne, Ukraine, postal code 33018 (slavatsetsik@gmail.com)

ORCID: https://orcid.org/0000-0002-2527-2155

Researcher ID: E-8054-2019 (http://www.researcherid.com/rid/E-8054-2019)

\section{Halyna MARTYNIUK}

PhD (Education), Associate Professor of the Department of Public Administration, Documentation and Information Activities of the National University of Water Management and Nature Management, 48 Tsentralna str, apt. 41, an urban-type settlement Orzhiv, Ukraine, postal code 33000 (qwer200707@meta.ua)

ORCID: https://orcid.org/ 0000-0003-1424-1289

Researcher ID: E-9327-2019 (http://www.researcherid.com/rid/E-9327-2019)

\section{Ярослав ЦЕЦИК}

кандидатісторичнихнаук, доценткафедридержавногоуправління, документознавства та інформаційної діяльності Національного університету водного господарства та природокористування, вул. Михайла Вербицького 18, Рівне, Украӥна, індекс 33018 (slavatsetsik@gmail.com)

\section{Галина МАРТИНЮК}

кандидат педагогічних наук, доиент кафедри державного управління, документознавства та інформаційної діяльності Національного університету водного господарства та природокористування, вул. Центральна 48, кв. 41, Оржів, Україна, індекс 33000 (qwer200707@meta.ua)

Бібліографічний опис статті: Tsetsyk, Ya, \& Martyniuk, H. (2019). The role of Russian Right-Wing radicals in the extension of interethnic relations in Volhynia during 1906 - 1914. Skhidnoievropeiskyi Istorychnyi Visnyk [East European Historical Bulletin], 13, 84-93. doi: 10.24919/2519-058x.13.188668

\section{THE ROLE OF RUSSIAN RIGHT-WING RADICALS IN THE EXTENSION OF INTERETHNIC RELATIONS IN VOLHYN DURING 1906 - 1914}

\footnotetext{
Abstract. The purpose of the article is to elucidate the role of the Russian right-wing radicals in complicating interethnic relations in the Volhynian Governorate and to find out about the involvement of the Orthodox clergy and authorities in these processes. The research methodology is based on the principles of author's objectivity, multifactoriality of sources, as well as the use of general scientific (analysis, synthesis, generalization), mathematical (statistical) and special-historical (historicalsystemic, comparative, retrospective) methods. The research novelty is that on the basis of previously
} 
researched documents the complex of actions, carried out by the Black Hundreds with the purpose of discrediting the representatives of other ethnic groups and confessions, has been found out. The Conclusions. The causes of the Black Hundred Movement have been identified and its main tasks have been analyzed. It has been determined that, compared to other political structures that operated in the Russian Empire during the period under study, the right-wing radicals enjoyed the support and patronage of not only the higher authorities but also the imperial family. That is why they had a considerable financial capacity to expand their advocacy activities in several directions. In fighting for the economic and political domination of the Russians in the Volhynian Governorate, the Black Hundreds used any means, which negatively affected the socio-political processes in the region. These trends intensified during World War I, when a flurry of baseless accusations fell on the German agrarian colonists, who were overwhelmingly politically passive. The Russian right-wing radicals justified the expediency of depriving some ethnic groups, especially the Jews, of the right to receive a secondary and tertiary education and to have access to a public service. Till present, the articles of a similar content have been published on the pages of the press. It was the Russian right-wing radicals, who greatly influenced the intensification of interethnic relations in the early twentieth century both in Volhynia and in the empire.

Key words: Volhynia, the Russian right-wing radicals, interethnic relations, authorities.

\section{РОЛЬ РОСІЙСЬКИХ ПРАВОРАДИКАЛІВ У ЗАГОСТРЕННІ МІЖНАЦІОНАЛЬНИХ ВЗАСМОВІДНОСИН НА ВОЛИНІ У 1906 - 1914 pp.}

Анотація. Мета статті - проаналізувати роль російських праворадикалів у загостренні міжетнічних взаємовідносин на Волині у 1906 - 1916 рр. 3'ясувати роль органів імперської влади та Російської православної иеркви у цих процесах. Методологія дослідження трунтується на принципах авторської об'єктивності, поліфакторності джерел, а також на використанні загальнонаукових (аналіз, синтез, узагальнення), математичних (статистичний) та спеціально-історичних (історико-системний, порівняльний, ретроспективний) методів. Наукова новизна полягає у тому, що на основі раніше недосліджених документів з'ясовано комплекс заходів, які здійснювали чорносотениі з метою дискредитачії представників іниих етнічних груп, конфесій. Висновки. 3'ясовано причини утворення чорносотенного руху та проаналізовано основні його завдання. Визначено, що у порівнянні з іншими політичними структурами, які у досліджуваний період функиіонували в Російській імперії, праворадикали користувалися підтримкою $і$ заступництвом не лише вищих органів влади, а й імператорської родини. Саме тому вони мали значні фінансові можсливості для розгортання своєї пропагандистської діяльності, яка проводилася в кількох напрямах. Ведучи боротьбу за економічне та політичне домінування росіян у Волинській губернії, чорносотенці використовували при цьому будь-які засоби, що негативно позначалося на суспільно-політичних прочесах у регіоні. Ці тендениї̈ посилилися під час Периої світової війни, коли на німечьких аграрних колоністів, які у своїй абсолютній більшості були політично пасивними, звалився шквал безпідставних звинувачень. Російські праворадикали обтрунтовували доцільність позбавлення окремих етнічних груп, насамперед євреїв, права отримувати середню та вищу освіту і мати доступ до державної служби. 3 цією метою на сторінках пресових органів часто друкувалися статті подібного змісту. Саме російські праворадикали великою мірою вплинули на загострення міжетнічних взаємовідносин на початку XX cm. як на Волині, так і в імперії.

Ключові слова: Волинь, російські праворадикали, міжнаціональні взаємовідносини, органи влади.

The Problem Statement. The importance of studying the activities of the Union of the Russian People in Volhynia in the early twentieth century is to determine the leading political landmarks of the Russian right-wing radicals in the early twentieth century; makes it possible to determine the role of imperial authorities in these processes and to determine the level of support of the Black Hundreds by the Orthodox clergy and governmental structures.

The Analysis of Recent Researches and Publications. The problem of the activity of the Russian right-wing radicals in the Volhynian Governorate has not been sufficiently investigated. 
The development of the right-wing movement in the empire, its social base and the peculiarities of women's participation are analyzed in the work of English scientist Gilbert (Gilbert, 2017). Some aspects of the activity of the Russian right-wing radicals were explored in the monograph on the activity of the Orthodox Church in Volhynia by S. I. Zhyliuk (Zhyliuk, 1996). The dynamics of the growth of the Black Hundreds in the empire initially and the reasons for the decline in the organization in the early 1910-ies and the mechanisms of their financing were explained by A. I. Kuritsyn (Kuritsyin, 2015). The main reasons for the strengthening of the position of the Russian right-wing radicals on the Ukrainian lands and the role in these processes of the imperial authorities were investigated by O. Obersht (Obersht, 2015). The Black Hundreds' attitude to other political groups and representatives of other ethnic groups, first of all, the Jews, was found out by R. O. Tokalenko (Tokalenko, 2017). The role of the Orthodox clergy in strengthening the position of the Black Hundreds in Volhynia and the main aspects of their advocacy work was traced by Yu. Khytrovska (Khytrovska, 2011).

The purpose of the article is to expose the role of the Russian right-wing radicals in complicating the interethnic relations in the Volhynian Governorate and to find out about the involvement of the Orthodox clergy and authorities in these processes.

The Statement of the Basic Material. In the early twentieth century, the socio-political situation in Volhynia was much more complicated. The Russian Orthodox Church (ROC) and the Union of the Russian People (URP), which was formed in the fall of 1905 in Petersburg, played an important role in exacerbating interethnic relations. At that time, the Russian rightwing movements reflected a new policy for the empire and much of Europe - anti-capitalist, anti-liberal and anti-Semitic, which was based on mass agitation, social activity and parliamentary participation. By the end of 1905 - the second half of 1906, the right unions were developing at a rapid pace. The membership of their workers and peasants was among the immediate priorities: in its manifesto prior to the election of the First State Duma of the URP demanded that these social classes be included in its movement in order to create the "effect of representation of all groups of Russian society" (Gilbert, 2017, p. 660).

As of 1907, more than 105,000 people were members of the Volhynian Governorate, and more than 300 of the URP's divisions and subdivisions were headed by worshipers. It was at this time that the Pochayiv Lavra was the leading center of the Black Hundred movement in Volhynia, and its archimandrite Vitalii was the leader of the local Black Hundreds (Khytrovska, 2011, p. 340). At the beginning of 1908, according to the Police Department, the URP ranked 404, 550 (Kuritsyin, 2015, p. 41), about 190,000 of them were in Ukrainian lands (Samartsev, p. 91). This can be explained by several reasons: firstly, the multiethnic population, where Russian merchants, landlords and officials felt pressure from Polish landlords and Jewish merchants; secondly, in Right-Bank Ukraine, where most of the landlords were Catholics, the Orthodox Church seemed to the peasants to defend their interests, so they gladly joined the right wing; thirdly, in order to attract as many supporters as possible, they created professional associations that included members of different sections of the population; and fourthly, the URP had close links with the authorities, got financial support, and received police support (Obersht, 2015, pp. 154-155). But in the following years, the number of monarchical organizations decreased significantly. Thus, in 1912 the total number of the right-wing organizations decreased to 45-60 thousand people. First of all, it was connected with the fall in the level of politicization of a public life, "the establishment by the government of the long-awaited "order", the inability of the Black Hundreds to resolve the agrarian question". Faced with the fact that the Black Hundreds could not and did not contribute to 
the endowment of peasants land, the latter began to massively leave the right organizations, including the URP. The decrease in the number of the right-wing organizations was also facilitated by the schisms that swept the URP during $1908-1911$. They were caused by the personal ambitions of party leaders, but also had a fundamental basis related to the attitude to the State Duma, the elimination of the community, the need to establish relationships with other parties (Kuritsyin, 2015, p. 41).

The leadership of the URP, which had all the hallmarks of the party (program, charter, governing bodies, an extensive network of regional organizations, etc.), categorically denied its party character. The "Union" was characterized by them as a nation-wide union, and in a broad sense, "identified with the whole "Russian" nation". In this interpretation, belonging to the URP "was not a voluntary choice, but a sacred duty of every faithful", and membership in other political groups equated to treason. The Black Hundreds advocated a ban on all but one party (Tokalenko, 2017, p. 48).

Based on the URP statute, the Pochayiv department of the URP statute was adopted. It stated that the purpose of the organization was to develop a "national Russian consciousness and a strong unification of Russian people of all the states and property of Volhynia and the neighbouring provinces for joint work in favour of our dear Motherland - Russia, united and indivisible" (Ustav Pochaevskogo Soyuza Russkogo naroda, 1906, pp. 1-2). Women were also allowed to join the organization (Gilbert, 2017, p. 660).

Since its formation, the organization has taken a frankly anti-Semitic stance. The statute, in particular, stated that "Jews may never be admitted to the Union as members"; for "foreigners", they could be admitted to the organization, but only according to the "resolution of the Board", but elected or leadership positions in the organization had the right to occupy only the Orthodox (Ustav Pochaevskogo Soyuza Russkogo naroda, 1906, p. 6). In addition to the pronounced anti-Semitic propaganda, the Black Hundreds in Volhynia also carried out active anti-Polish and anti-German propaganda, which to a large extent led to complications and so difficult interethnic relations in the region.

Trying to portray themselves as the defenders of peasants' interests, the Black Hundreds sought to blame the poor society of that time, while promoting the organization's ideology. For this purpose, tens of thousands of brochures and various proclamations were published in the Pochayiv Lavra printing press, often calling out the "fight of the Jews and students". Only at the end of 1906 the Pochayiv Department of the URP printed out 36,000 brochures and 30,000 leaflets that were distributed in villages (Zhyliuk, 1996 p. 121; Khytrovska, 2011, p. 340). The publication of such brochures continued during the following years. This activity of the URP was aimed at strengthening its influence in Volhynia and at discrediting its opponents.

The analysis of the content of these printed products shows that it was aimed not only at the dissemination of the Black Hundred ideology, but also had a frank anti-Polish, anti-Protestant and Judophobic character. In one of the editions entitled Religion of the Jews. The Talmud and its teachings on Christians it was emphasized that "The doctrine of God here is an extreme anthropomorphism" (M. A. b, 1914, p. 5). The focus was on the "Activity of the Judeo-Masons" and the "Organization of the Judeo-Masons", which "penetrated everywhere and almost took into its hands the entire supreme power over the world". Like, when they came to power, they, "without neglecting any means", tried in all states to pursue the "foreign and domestic policies that are most beneficial to them" (M. A. b, 1914, pp. 9-13). It was also argued that in order to weaken the power of the state, the Jews sought, with the help of 
the Social Democrats, to realize the need to reform the entire polity through "its complete destruction and transition to a democratic basis" (M. A. b, 1914, p. 14).

Another pamphlet entitled One of the Causes of Our Poverty stated that it was the "Democrats", who instructed the poor peasants in 1904 - 1905 how to become wealthy, namely: the peasants had to take their land from the landowners, cut down the forest, and "in some places it happened", as a result of which some of the rebel peasants were executed, some of them were sent to prison. Separately, it was argued that the Jews "persuaded peasants to commit crimes" (Odna iz prichin nashey nischetyi, 1913, pp. 1-3). Another cause of poverty was the fact that all trade business in the Western Territory was concentrated in the hands of the Jews, and they were profiting at the expense of the peasants. Therefore, to counter the Jews, the peasants had to unite and open consumer shops that were part of the structure of the Pochayiv department of the URP (Odna iz prichin nashey nischetyi, 1913, pp. 4-31).

Thus, the Black Hundreds' agitation brochures clearly showed a tendency to accuse the Jews of trying to weaken state power in order to benefit from it, to organize revolutionary protests and to encourage peasants to participate in them, to inflate the prices of goods they sold in the region.

While doing everything necessary to strengthen the position of the ROC in the region, the URP officials published a series of brochures analyzing the Church's tenets. One of them emphasized that there were two ways: the true path and the false one. Only those, who adhere to the canons of the church and the "Holy Scriptures" follow the "true path", and all others are not the Christians (Litvinovich, 1913, pp. 1-8). Another brochure said that an important role in the development of the state was played by the family, which was the primary link in society. Therefore, the relationship between its members should be based on mutual respect and "mutual respect for children and parents". And admiration for Western ideas had a negative effect on family relationships in Russian families (Razval russkoy semi, 1913, p. 5).

So, as we can see, in addition to the political component, the Black Hundreds also paid considerable attention to the development of "spirituality" of the local population and substantiated the ROC's conception of the negative influence of Western culture on the Russian state. One of their arguments was that it was the Western ideas that fascinated the people of the empire had a negative impact on family relationships.

It should be noted that the Black Hundreds had considerable financial resources for their activities. Thus, the "Union members" had their own bank - the "Volhynia-Pochayiv People's Credit", which was opened on the initiative of Vitalii, archimandrite of Pochayiv Lavra. In addition, they received funds not only from individuals but also from public organizations. Thus, in December 1906, the Volhynia Committee on People's Temperance gave Lavra 1 thousand rubles. As of mid-December 1906, they collected membership dues of 13 thousand rubles (Zhyliuk, 1996, p. 121; Khytrovska, 2011, p. 341).

As the well-known publicist V. P. Obninskiy wrote at the time, in order to counter the revolutionary speeches, the provincial administrations were instructed to organize "patriotic demonstrations", involving "all suitable elements, not excluding schools". However, these demonstrations ended as quickly as they began, but they gave the government experience in promoting "counter-revolution", the organization of pogroms, and the organization of the URP itself (Obninskiy, 1912, pp. 152-153). After all, the "police state system that had no roots in the people" was forced to search for it and found it in the existing realities and among the inhabitants of urban slums (Obninskiy, 1912, pp. 153-156). 
The Black Hundreds traditionally opposed Catholics and Greek Catholics. In addition to publications in the periodical, a number of brochures were published in Pochayiv. In one of them it was stated that "the Union was imposed in Malorosiya a by force. Churches were selected, leased to the Jews, the holy vessels and shirts were polluted. People were mortified, burned alive, and churches replaced with pubs" (Lutsik, 1913, p. 19). It was further emphasized that the Catholic priests, the Polish king and the nobility did so in the "order of the Pope". Analyzing the situation at the beginning of the twentieth century, the Black Hundreds noted that Greek Catholic priests, in the place of worship, uttered the "Orthodox faith and the church instead of teaching" the parishioners of the "faith" (Lutsik,1913, pp. 19-22).

In another brochure, the author claimed that the region's residents were often tolerant to Catholics. This caused dissatisfaction with the leaders of the URP and the ROC, who at all costs tried to complicate interfaith relations in the province. In this connection it was emphasized that it was the Catholics, who mocked and abused the Orthodox faith, called it "boorish", and leased it to the Jews of the church (Kratkoe slovo o katolichestve, 1911, p. 4). Further, the differences in church services were analyzed and it was authoritatively stated that it was the Roman Catholics, who departed from the "true dogmas" of the Christian faith and were strictly adhered to by the ROC (Kratkoe slovo o katolichestve, 1911, pp. 5-9). This position of the Black Hundreds was dictated by the fact that most of the landowners in the region were Polish Catholics, to whom the imperial power was prejudiced. And the sharp increase in the number of Catholics in the region was negatively perceived by the ROC. Thus, among the large and medium-sized landowners of the Volodymyr-Volynskyi County, the Poles dominated (State Archive of Volyn Region, f. 374, d. 1, c. 1, pp. 1-4). Similar trends were observed in other counties in the region.

One of the brochures issued on the eve of World War I, which bore a frankly Jewish character, noted that it was the Jews who, in order to establish their dominion over the Christian states, made a very important act by possessing three powerful means, namely: "capital, participation in political parliaments and finally the press" (M. A. a, 1914, p. 4). Further, the author, while analyzing the situation in the sphere of economic and political activity of the Jews, focused on the fact that in the late nineteenth - early twentieth centuries, their positions were greatly strengthened, which threatened the security of the empire. In order to successfully counteract Jewish capital, the URP had to receive a financial assistance from the authorities in order to be able to control trade in the western provinces, build elevators, and thus prevented the Jews from buying them. In the end, the inhabitants of the region were taught to successfully counter the Jews "it is necessary... to begin with a systematic exposition of the Jews, so that everyone clearly understands that, by selling or buying from the Jews, they are sinning against God, the King, and their Christian brothers" (M. A. a, 1914, pp. 5-20). This brochure contained not only political but also economic implications. After all, in the early twentieth century, it was the Jewish capital that dominated the trade in Volhynia. Thus, according to the documents of the Lutsk City Council in 1902, the vast majority of merchants who were entitled to trade were the Jews (SAVR, f. 3, d. 1, c. 443, pp. 68-79). Similar trends were observed in other counties of the region, as it was the Jews, who made up the majority of the inhabitants of Volhynian cities at that time.

Consequently, in a series of brochures, the Black Hundreds urged the region's residents to boycott Jewish trade establishments, while attempting to take control of the trading operations, asking the government to properly credit the Black Hundreds.

In addition to the brochures, which appeared to be huge for the period under review, the Black Hundreds also promoted their ideology in a number of press publications published in 
Volhynia. In addition to the propaganda of the Black Hundred ideas, they published a large number of articles of anti-Polish, anti-Jewish and anti-German content. This line of activity of the URP was conducted in the context of the domestic policy of the empire during that period. In this context, the position of the Russian emperor on the URP's activities should also be clarified. He, together with the heir to the throne, became not only a member of the "Union", but also gave about 12 million rubles for the needs of the organization from his own funds (Khytrovska, 2011, p. 341).

The Black Hundreds, together with the ROC clergy, actively opposed the Protestants. To this end, the Pochayiv Lavra has repeatedly organized relevant "missionary courses", held meetings to decide how to counteract the influence of the Protestant communities. Thus, on 2 March 1916, a meeting of the Volhynian "anti-sectarian mission" was to take place. It was to consider the question of "the means of sectarian propaganda, especially of Stundinism, and the best means of combating sectarianism". Strengthening the anti-Protestant actions, they argued as a struggle against "all foreign" and the manifestation of "state patriotism" (Platonov, 1916, p. 3). This attitude of the Black Hundreds towards the Protestants was caused by the fact that after the decree of Nicholas II "On the Principles of Tolerance" of 17 May 1905, the number of the Protestants in the region increased. The foundations of the Protestant doctrine were brought to the region by German agrarian colonists, who lived in Volhynia on the eve of World War I, the home to approximately 200,000 people. Therefore, one of the URP's activities was anti-German propaganda, which intensified after the outbreak of the war. The attention was drawn to the fact that more than 11,000 students received education in 280 German schools as of 1913 (Pamyatnaya knijka Volyinskoy gubernii na 1914 god, 1913, p. 90). Concerning the level of teaching, the author of the article assured that some teachers of these schools had "teaching abilities that are not better than the teaching abilities of German Feldwebels". At the same time, there was a requirement to end the autonomy of the schools in the German colonies and to change them into the Russian language of instruction. At the same time, it was emphasized that the directors of public schools repeatedly appealed to the Trustee of the Kyiv Educational District, however, despite the war, this issue was not resolved (Revnikov, 1915, pp. 3-4).

The imperial authorities kept records of all German and Czech agrarian colonists, who lived in Volhynia. Separately, it was stated whether they were subjects of the Russian Empire or foreign states. They also kept records of their property, their family members and their living arrangements. Thus, in a number of settlements of Zhytomyr County in the early twentieth century the Czech and German colonists, who were not subject to the empire, lived compactly (State Archives of Zhytomyr Region, f. 70, d. 1, c. 858, pp. 4-12). A similar situation was found in other counties, in particular in Kovelskyi one (SAZR, f. 70, d. 1. c. 861, pp. 2-13).

Thus, the Black Hundreds URP officials opposed the teaching of the German language in schools operating in German colonies. And given the war with the Kaiser Germans, they offered to change their studies into Russian and replace German teachers with Russians.

Traditionally, the negative attitude towards the Jews was repeatedly reflected on the pages of press bodies and in the articles by authors, who shared the views of the Black Hundreds. In one of them it was told that the soldiers of one of the military units, being captured, hid the flag and tried to keep it, but "one such soldier was issued by a Jew". The German military did not find him during the search. Then all the "captives were stripped and driven out into the cold" and so "kept for 4 hours, and everything was interrupted in the barracks and 
the flag was found". As a result, "many soldiers died". And it was further written that the Jews betrayed German soldiers and the Cossacks, who were surrounded, so in the army "anger against Jewish betrayal, cowardice and meanness" captured even those who previously sympathized with them. Instead, according to the author of the article, "streams of dirt on the Russian people, on the Russian society are pouring" from the pages of the Jewish press only because "the Russian people do not want to submit to the more terrible than the German one, to the Jewish one". Therefore, in the author's view, to equate the Jews in rights with the "traitorous Russian people" was "a great image that can only be thrown into the face of this people" (K voprosu o ravnopravii evreev, 1915, pp. 3-4).

Another publication stated that in the town of Volodymyrets of Lutsk County, which was a considerable distance away from the county center, there were many Jews, who provided loans to local peasants and returned the last percentages with food and labour. In addition, the local Jews controlled all trade. In connection with this, "boozing, and with its companion hooliganism", became widely known in the town. After all, "the Jew considers it his legal duty to provide all the hospitality and earn 9 cents on a bottle of vodka". Separately, the author noted that the Jews deliberately inflated prices for certain groups of goods and thus made money at the expense of local peasants. As one of the key options for ending Jewish domination in trade, the author suggested limiting their rights. At the same time, the author was indignant that local officials supported the Jews and did not pay attention to the violations on their part (Nekagalnyiy, 1914, pp. 1-2).

One of the levers of increasing Russian influence and counteraction to the Jews, the Poles, and the representatives of other ethnic groups suggested: "accepting the Hessen and Petrozhytskyi title of the "Black Hundred", we must ... stop the Judeo-foreign flood of middle and high school and bring our native Russian people to high school world". As one of the mechanisms it was proposed to reform the secondary school, "to introduce the doctrine of the harmful nature of the Talmud, of Jewish nationality and Freemasonry into the course as a compulsory subject for the upper classes; to destroy the Jewish press and the Jewish agitation", and also required laws that would discredit the Russians, who had married baptized or non-baptized Jews. It was also proposed to "deprive the persons of the Jewish blood", whatever condition they belonged to, "the right to receive ranks and orders" which gave the right to the nobility; the right to enter public service, "the Imperial Universities and theaters". When these laws are enacted, in "20-30 years Russia, suffocating in the throes of foreigners, will take a break and say Russian thank you" (Venojinskiy, 1914, pp. 2-3).

Thus, at the beginning of World War I, the Black Hundreds intensified their activities, which had a frankly Judophobic character. An analysis of the above publications shows that the ideologues of the URP, using the support of power structures, often, without strong arguments, accused the Jews of anti-state activity. As a recipe for counteracting them, they offered to further restrict their rights.

The Conclusions. Thus, the activities of the Black Hundreds in Volhyn caused the complication of such difficult interethnic relations. Thanks to the support of the authorities and the Orthodox clergy, the URP quickly gained leadership in the political life of the region. The Black Hundreds pursued blatant anti-Semitic, anti-Polish, and anti-Protestant activities in the course of imperial politics at the time, which was reflected in many articles and special editions. At the same time, they were certainly in support of the Russian autocracy, and they actively opposed other political structures that were different from their ideology. The Russian right-wing radicals justified the expediency of depriving some ethnic groups, especially 
the Jews, of the right to receive a secondary and tertiary education and to have access to public service. To this end, the articles of a similar content were often published on the pages of the press bodies, which negatively affected the socio-political situation in the region and stimulated the intensification of interethnic relations.

Acknowledgments We would like to thank the staff of the State Archives of Volyn and Zhytomyr regions whose documents were used during the writing of the article.

Funding. The authors received no financial support for the research, authorship, and/or publication of this article.

\section{BIBLIOGRAPHY}

Derzhavnyi arkhiv Volynskoi oblasti [State Archive of Volyn Region - SAVR].

Derzhavnyi arkhiv Zhytomyrskoi oblasti [State Archive of Zhytomyr Region-SAZR].

Gilbert, Dzh. (2017). Zhenschinyi, natsionalizm i rossiyskie pravyie organizatsii $(1905-1917)$ [Women, Nationalism and the Russian right (1905 - 1917)]. Quaestio Rossica, 5, (3), 656-674. doi: 10.15826/qr.2017.3.243 [in Russian]

K voprosu. (1915). K voprosu o ravnopravii evreev [On the issue of Jewish equality]. Jizn Volyini, 235, 12 avgusta, 5. [in Russian]

Khytrovska, Yu. V. (2011). Uchast khrystyianskykh konfesii u suspilno-politychnomu zhytti Ukrainy naprykintsi XVIII - na pochatku XX st. [Participation of Christian denominations in the social and political life of Ukraine in the late XIXth - early XXth centuries]. Kyiv: Vydavnytstvo yevropeiskoho universytetu, $472 \mathrm{p}$. [in Ukrainian]

Kratkoe (1911). Kratkoe slovo o katolichestve [A short word about Catholicism]. Pochaev: Tipografiya Pochaevo-Uspenskoy Lavryi, 11 p. [in Russian]

Kuritsyin, A. I. (2015). Finansirovanie i chislennost Soyuza russkogo naroda v pokazaniyah N. E. Markova [Financing and size of the Union of the Russian people in the testimony of N. E. Markov]. Vestnik BDU, (3), 39-45. [in Russian]

Litvinovich, I. (1913). Dva puti [Two ways]. Pochaev: Tipografiya Pochaevo-Uspenskoy Lavryi, 8 p. [in Russian]

Lutsik, K. (1913). Gde pravda? Pravoslavnyim i uniatam pod razvagu peredae [Where is the truth? Orthodox and Uniates]. Pochaev: Tipografiya Pochaevo-Uspenskoy Lavryi, 28 p. [in Russian]

M. A. (1914a). Velichie Rossii-v razobschenii s jidami [Greatness of Russia-in isolation with the Jews]. Pochaev: Tipografiya Pochaevo-Uspenskoy Lavryi, 20 p. [in Russian]

M. A. (1914b). Religiya jidov. Talmud i ego uchenie kasatelno hristian [Religion of the Jews. The Talmud and its teaching about Christians]. Pochaev: Izdatelstvo Pochaevo-Uspenskoy Lavryi, 23 p. [in Russian]

Nekagalnyiy, S. (1914.) Kartinki iz mestnoy jizni. Nashi poryadki [Pictures from local life. Our orders]. Volyinskaya zemlya, 64, 7 marta, 1-2. [in Russian]

Oberszt, O. (2015). Radikalnyie russkie natsionalisticheskie organizatsii na territorii Ukrainyi (1905 - 1914) [Radical Russian nationalist organizations in Ukraine (1905 - 1914)]. Acta scientifica academiae ostrovensis. Sectio a nauki humanistyczne, spoєeczne i techniczne, 5 (1), 146-159. [in Russian]

Obninskiy, V. P. (1912). Poslednmy samoderjets: Ocherk jizni i tsarstvovaniya imperatora Rossii Nikolaya II-go. [The last autocrat: Essay on the life and reign of Emperor of Russia Nicholas II]. Berlin: Eberhard Frowein Verlag, 562 p. [in Russian]

Odna (1913). Odna iz prichin nashey nischetyi [One of the reasons for our poverty]. Pochaev: Tipografiya Pochaevo-Uspenskoy Lavryi, 31 p. [in Russian]

Pamyatnaya (1913). Pamyatnaya knijka Volyinskoy gubernii na 1914 god [The memorial book of the Volyn province for 1914]. Jitomir: Volyinskaya gubernskaya tipografiya, 549 p. [in Russian]

Platonov, A. (1916). Missionerskoe soveschanie [Mission meeting]. Jizn Volyini, 54, 24 fevralya, 3. [in Russian]

Razval (1913). Razval russkoy semi [The collapse of the Russian family]. Pochaev: Tipografiya Pochaevo-Uspenskoy Lavry, 7 p. [in Russian] 
Revnikov, A. (1915) Nemtsyi na Volyini. Nemetskie shkolyi [The Germans in Volyn. German schools]. Jizn Volyini, 54, 24 fevralya, 3-4. [in Russian]

Samartsev, I. H. (1992). Chornosotentsi na Ukraini (1905 - 1917 rr.) [Black Hundreds in Ukraine (1905 - 1917)]. Ukrainskyi istorychnyi zhurnal, 1, 90-98. [in Ukrainian]

Ustav Pochaevskogo (1906). Ustav Pochaevskogo Soyuza Russkogo naroda [Charter of the Pochaev Union of the Russian people]. Pochaev: Izdatelstvo Pochaevo-Uspenskoy Lavryi, 12 p. [in Russian]

Venojinskiy, V. (1914). Gospodstvuyuschee polojenie jidov i inorodtsev [The dominant position of the Jews and foreigners]. Volyinskaya zemlya, 183, 12 iyunya, 2-3. [in Russian]

Zhyliuk, S. I. (1996). Rosiiska pravoslavna tserkva na Volyni (1793 - 1917) [Russian Orthodox Church in Volyn (1793 - 1917)]. Zhytomyr: Zhurfond, 176 p. [in Ukrainian]

Tokalenko, P. O. (2017). "Chorna sotnia”. Diialnist monarkhichnykh orhanizatsii na Pivdni Ukrainy a roky Pershoi rosiiskoi revoliutsii ["The Black Hundreds". Activity of Monarchical Organizations in the Southern of Ukraine in the Years of the First Russian Revolution]. Visnyk Kharkivskoho natsionalnoho universytetu imeni V. N. Karazina. Seriia «Istoriia Ukrainy. Ukrainoznavstvo: istorychni ta filosofski nauky». (25), 46-53. doi: 10.26565/2225-6505-2017-2-6 [in Ukrainian]

The article was received on April 29, 2019. Article recommended for publishing 06/11/2019. 